\title{
Migration Parks and Monuments to Multiculturalism
}

\author{
Finding the Challenge to Australian Heritage Discourses \\ through Community Public History Practice
}

Alexandra Dellios

\begin{abstract}
In this article, I "read against the grain" of a monument to post-WWII immigration and migrant communities. I am concerned with how such monuments, locally situated, might be used in more progressive and transformative histories, ones that harbor the potential to challenge existing public and collective memories of postwar migration and multiculturalism that occur on a national stage and within the ambit of Australia's heritage industry. This is a study in how discursively marginalized migrant groups, with subaltern narratives about mobility and settlement, claim space for alternative histories in the context of a restrictive official heritage.
\end{abstract}

KEY WORDS: multiculturalism, heritage, migration, monument, ethnic

In this article, I intentionally read against the grain of a monument to migration: the Gippsland Immigration Park, which was erected by a community group in southeastern Australia in the coal-rich region of the Latrobe Valley. I am concerned with how community-initiated monuments might contribute to progressive and transformative histories, ones that harbor the potential to challenge existing public and collective memories of postwar migration and multiculturalism that occur on a national stage and within the ambit of Australia's heritage industry. "Industry" refers to various national and state heritage bodies, the lists and registers they police, and the national and international (ICOMOS) charters and definitions to which they adhere. This realm of heritage legislation and the discourse it produces is one manifestation of "heritage" in which we can see how versions of the past are intimately connected to cultural power, as David C. Harvey has argued. ${ }^{1}$ My concern over migration history's encounter with the heritage industry, and the industry's complicity with the state policy of multiculturalism, rests with the limitations and obfuscations it may produce: that is, the loss of marginalized, and especially

I David C. Harvey, "Heritage Pasts and Heritage Presents: Temporality, Meaning and the Scope of Heritage Studies," International Journal of Heritage Studies 7, no. 4 (2001): 319-38.

THE PUBLIC HISTORIAN, Vol. 42, No. 2, pp. 7-32 (May 2020). ISSN: O272-3433, electronic ISSN 1533-8576. (C) 2020 by The Regents of the University of California and the National Council on Public History. All rights reserved. Please direct all requests for permission to photocopy or reproduce article content through the University of California Press's Reprints and Permissions web page, https://www.ucpress.edu/journals/reprints-permissions. DOI: https://doi.org/IO.I525/tph.2020.42.2.7. 
working class, histories in state-endorsed framings that celebrate notions of economic progress and superficial cultural "contributions." This will be explained in reference to Australian multiculturalism. Although locally situated and framed by a particular understanding of Australian multiculturalism, this analysis has applicability elsewhere. This is a study in how discursively marginalized migrant groups, with subaltern narratives about mobility, labor, and settlement, claim a space for alternative histories in the context of a restrictive official heritage.

I am not searching for easy solutions to the silences inherent in this exclusionary heritage landscape, nor do I wish to perpetuate a dichotomous understanding of official and unofficial heritage practices. In recent years, heritage managers and public historians working in the industry in Australia have tried to produce a practice that privileges evolving "social values" rather than maintaining a practice that reproduces static, elitist, and predominately Western notions of heritage. ${ }^{2}$ The latter has been theorized as an authorized heritage discourse (AHD) by Laurajane Smith, who argues that an AHD privileges the cultural symbols of a particular social group (often white and middle or upper class). This discourse also limits the right to identify and champion this "heritage" to groups with "expertise" (the architects, archaeologists, and-a more recent creation-the heritage manager). To a degree, practice has responded to these mostly academic charges by adding provisos to prominent charters, like Australia's ICOMOS Burra Charter, about greater inclusion and "plurality"; but such additions are unable to fully unravel or decenter "the firmly established and authoritative discourse of the expert," and break away from monolithic and linear narratives. ${ }^{3}$ Conversely, as Graeme Davison urged in 20I3, the primary challenge for the heritage industry might not rest in refining management techniques, but rather in nourishing the relationship of community trust. ${ }^{4}$ Along this vein, other scholars have argued that reforms to heritage management techniques, in the form of new ICOMOS charters, seem better equipped to strengthen the voices of national governments rather than foster participatory and locally led heritage management. ${ }^{5}$ Community engagement in heritage, and

2 Annie Clarke and Chris Johnston, "Time, Memory, Place and Land: Social Meaning and Heritage Conservation in Australia," paper presented at the Scientific Symposium, ICOMOS I4th General Assembly, Victoria Falls, Zimbabwe, October, 2003, I-6; Denis Byrne, Helen Brayshaw, and Tracy Ireland, Social Significance: A Discussion Paper (NSW National Parks and Wildlife Service, Research Unit, Cultural Heritage Division, 200I). Also, the work of Melbourne-based Context Heritage Consultants and GML Heritage Management in Sydney and Canberra have been dominant here. Chris Johnston from Context (and co-convenor of Australia ICOMOS Intangible Cultural Heritage National Scientific Committee) has advocated for a more holistic approach to assessing significance that integrates community knowledge and intangible heritage.

3 See Emma Waterton, Laurajane Smith, and Gary Campbell, "The Utility of Discourse Analysis to Heritage Studies: The Burra Charter and Social Inclusion," International Journal of Heritage Studies I2, no. 4 (2006): 339-55.

4 Graeme Davison, "My Heritage Trail," in Australian History Now, ed. Anna Clark and Paul Ashton (Sydney: NewSouth Publishing, 2013), I88.

5 Bahar Aykan, "How Participatory is Participatory Heritage Management? The Politics of Safeguarding the Alevi Semah Ritual as Intangible Heritage," International Journal of Cultural Property 20, no. 4 (2013): 38I-405; Thomas Beardslee, "Whom Does Heritage Empower, and Whom 
community understandings of their own pasts, remain underprivileged by the heritage industry.

Recent literature has sought to understand the function of discourse in the heritage industry and how heritage is received and consumed by different community audiences. ${ }^{6}$ I propose that academics in critical heritage studies also look to community-initiated examples of migration heritage, those public history projects that may not make it on heritage lists or become the subjects of conservation management plans-those smaller, community-initiated and led projects. We can look to these examples to explore the challenge that grassroots public history practice may pose to more mainstream and officially endorsed framings of heritage and other official renditions of the past.

Gippsland Immigration Park (GIP) both draws on circulating discourses (around state multiculturalism) and also harbors the potential to challenge the limits of those discourses by foregrounding the working class and mobile histories they ignore. These community versions of history are not always linear, and they can contain contradictory national and local tropes of progress and success. The group behind the park is not a homogenous group, but they do not represent the attitudes of all communities in the Latrobe Valley-particularly when it comes to their approach to industrial heritage and histories of labor and migration in postwar Australia. The park contains its own gaps and silences, but as I will demonstrate it offers specific historically grounded narratives of immigration and labor that hold the potential to challenge the limits of Australian multiculturalism and heritage practice.

\section{Historical Context}

Australia's past is largely defined by immigration and displacement. Government policy enabling and encouraging migration and settlement, as well as the oftenviolent displacement of Indigenous peoples since European invasion in I788, has wrought massive environmental, social, and cultural changes on the landscape. After WWII, the Commonwealth Government initiated a mass immigration scheme that recruited new citizens from beyond the British Isles. Australia's first minister for immigration, Arthur Calwell, was both the architect of the first stage of the mass immigration scheme and a life-long advocate of the White Australia Policy. ${ }^{7} \mathrm{He}$ argued that Australia needed to rapidly increase its population to both boost its defenses in the Asian region and to achieve economic growth and full employment. Australia subsequently received and encouraged migration from Eastern and

Does It Silence? Intangible Cultural Heritage at the Jemaa el Fnaa, Marrakech,” International Journal of Heritage Studies 22, no. 2 (2016): 89-10I.

6 Emma Waterton and Laurajane Smith, "The Recognition and Misrecognition of Community Heritage," International Journal of Heritage Studies I6, no. I-2 (2010): 4-15; Emma Waterton and Steve Watson, "Heritage and Community Engagement," International Journal of Heritage Studies: Special Issue $\mathrm{I} 6$, no. I-2 (2010): I-3.

7 See Gwenda Tavan, The Long, Slow Death of White Australia (Carlton North, Victoria: Scribe, 2005). 
Southern European nations from which it had previously restricted immigration, including Poland, Greece, and Italy. ${ }^{8}$ The period after the end of WWII and until the I970s was defined by substantial industrial growth and full employment, due largely to the mass immigration scheme. Calwell's successors in the Liberal Party slowly whittled away at the ideology and restrictions of a racially discriminatory immigration policy until it was formally abolished by a Labor government in 1972.

One million people migrated to Australia in each of the six decades following 1950-mostly from Britain, Eastern and Southern Europe, and as the White Australia Policy waned, from the Middle East and Asia. I will discuss the conditions they faced when I address the case study of Gippsland. The clear economic successes of postwar migration, and now the positivist revisionist tendency to locate the beginnings of the nation's current superficial multiculturalism in the postwar era, risks concealing the lived and intimate realities of the mass immigration scheme, and the structural inequalities endured by generations of migrants. ${ }^{9}$ Australia's cultural and social life was transformed as a direct, albeit unintended, outcome of those decades of mass migration. And while some historians are increasingly interested in migration histories, Australia's migrant history has been fodder for populist, historically vacuous, unifying narratives for the nation-state, as historians Gwenda Tavan and Klaus Neumann have argued. ${ }^{10}$

\section{Multiculturalism in Australia}

Multiculturalism is still a publicly celebrated aspect of Australia's national identity and history. ${ }^{11}$ It evolved from its origins in the I970s as a set of policies providing much-needed special services for new and older non-English-speakingbackground (NESB) migrant cohorts. A vocal minority of critics-prominent right-wing academics and politicians-routinely attack the policy and the wider concept of multiculturalism. However, whereas other nations (Germany, France, and the UK) have moved away from the label in favor of policy words like "integration" and "social cohesion," multiculturalism continues to be used in the Australian policy context, despite significant reductions in funding to migrant and ethnic community affiliated welfare groups. ${ }^{12}$ On a descriptive level, and beyond its

8 Arthur Calwell cited in Klaus Neumann, Across the Seas: Australia's Response to Refugees: A History (Melbourne: Black Inc., 20I5), 8I.

9 Alexandra Dellios, Histories of Controversy: Bonegilla Migrant Centre (Melbourne: Melbourne University Publishing, 2017), 3.

Io Gwenda Tavan and Klaus Neumann, eds., Does History Matter?: Making and Debating Citizenship: Immigration and Refugee Policy in Australia and NZ (Canberra: ANU Press, 200I), 9; see also Ruth Balint and Zora Simic, "Histories of Migrants and Refugees in Australia," Australian Historical Studies 49, no. 3 (2018): $378-409$.

II Turnbull cited in David Sharaz, "United, Strong, Successful: PM Releases Statement on Multiculturalism," SBS News, March 20, 20I7, https://www.sbs.com.au/news/united-strongsuccessful-pm-releases-statement-on-multiculturalism.

I2 Anthony Moran, "Multiculturalism as Nation-building in Australia: Inclusive National Identity and the Embrace of Diversity," Ethnic and Racial Studies 34, no. I2 (20II): 2153-72. 
framing as a settlement policy, the discourse of multiculturalism forms part of a success story that begins in the postwar era of mass immigration and explicitly lends agency and foresight to government policy and "mainstream" Australian (imagined as Anglo-Celtic) acceptance of cultural difference, especially if it comes in the palatable (and politically neutral) form of food and folklore. ${ }^{13}$ Australian multiculturalism is also tempered, as it always has been to some degree, by an emphasis on the "privileges" of Australian citizenship and a stress on the civic responsibilities that apparently unify those lucky enough to be counted in the multicultural state. Here is one example of this rhetoric, a description attached to the Australian government's 2019 "Fostering Integration Grants":

Australia is a successful multicultural nation. We have flourished in part thanks to our cultural diversity, underpinned by our common values and commitment to freedom, security and prosperity. The Department of Home Affairs continues to nurture our socially cohesive society by supporting the integration of migrants. ${ }^{14}$

It is civic values that are said to unite Australia in diversity; but an extractive and unequal power dynamic prevails between a broadly conceived Anglo-Australian core and the ethnic others that fringe it. ${ }^{15}$ Similar critiques have been made of multiculturalism around the world, including its iterations in Canada and the United Kingdom. ${ }^{16}$ As Jo Littler and Roshi Naidoo argue, "these critiques need to be got out, dusted down and brought to bear on discourses of social exclusion and cultural diversity that are part of the current heritage agenda," both in the UK and elsewhere. ${ }^{17}$

\section{Migration in Heritage Practice}

In Australia, heritage grants and lists governing the conservation and management of physical structures are administered at national (the National Heritage List), state (State Heritage Registers), and local levels (heritage overlay). The ICOMOS Burra Charter, first released in I98I and based on the 1964 Venice Charter, guides "best practices" in all of these cases; it is referred to by heritage practitioners working in state-funded or independent heritage companies that conduct

I3 Stephen Castles et al., Immigration and Australia: Myths and Realities (Sydney: Allen \& Unwin in conjunction with the Housing Industry Association, 1998), 54; See also the latest multicultural statement, delivered by the Liberal government in March 2017, Multicultural Australia-United, Strong, Successful, https://www.homeaffairs.gov.au/trav/life/multicultural/multicultural-statement.

I4 "Multicultural Affairs and Citizenship Program: Fostering Integration Grants," 20I9, https:// www.communitygrants.gov.au/grants/fostering-integration-grants.

I5 For more on this version of civic multiculturalism in Australia, see Tim Soutphommasane, Don't Go Back to Where You Came from: Why Multiculturalism Works (Sydney: UNSW Press, 20I2).

I6 Sneja Gunew, Haunted Nations: The Colonial Dimensions of Multiculturalisms (London: Routledge, 20I3); Jo Littler and Roshi Naidoo, eds., The Politics of Heritage: The Legacies of Race (London: Routledge, 2004).

I7 Littler and Naidoo, The Politics of Heritage, Io7. 
significance assessments and conservation management plans for separate sites and collections. ${ }^{18}$ As heritage scholar Amy Clarke explains, "we are contributorssometimes knowingly and other times unconsciously-to historical narratives that are infused with identity politics, power imbalances, and long unchallenged paradigms."19

Migration has never had a prominent place in these lists or registers. In recognition of the lack of migrant places on the (now defunct) Register of the National Estate (1975-2003), the Australian Government funded the Australian Heritage Commission in the late I99os and early 2000 s to create a "Migrant Heritage in Australia Kit." 20 The project intended to help migrant communities identify "their own" heritage places-but its uptake by communities, then and now, is hard to ascertain. Both Bonegilla Migrant Reception and Training Centre and the Snowy Mountains Scheme were added to the new National Heritage List after 2003. My point here is not to push for the inclusion of more migrant places as national heritage, but to locate challenges to limited historical framings. On reflection, the kit was also a means to align peripheral places and memories with the official taxonomies and heritage discourses of the Australian Heritage Commissionensuring "special places associated with our more recent history of immigration are appreciated and cared for as part of Australia's heritage." 21 Such initiatives are bound by a celebratory multiculturalism that does not decenter limited definitions of mainstream heritage.

The National Heritage List contains only two sites that pertain explicitly to the nation's recent history of immigration. ${ }^{22}$ Both Bonegilla Migrant Reception and Training Centre in rural Victoria (listed in 2007) and the Snowy Mountains Hydro Electricity Scheme (listed in 20I6) have been deployed to highlight the successes of the postwar immigration scheme, industrial and economic progress, and the eventual creation of a harmonious and multicultural populace, and therefore to highlight government foresight. ${ }^{23}$ I want to suggest that the state-endorsed narratives

I8 Peter Spearritt, “Essay: What is Heritage?” Australian Heritage Strategy, Commissioned Essay, Department of Sustainability, Environment, Water, Population and Communities, 20I2, http://www. environment.gov.au/topics/heritage/australian-heritage-strategy/commissioned-essays.

I9 Amy Clarke, Cut Dewi, Kelly Greenop, Ali Mozaffari, Khoo Salma, Nigel Westbrook, and Tim Winter, "Reflecting on the Politics of Patrimony," Fabrications 28, no. 2 (2018): 256.

20 The RNE is now an archive of more than 13,000 places. After 2003 , and under the EPBC Act (Environment Protection and Biodiversity Conservation Act 1999), two new lists were created: the National Heritage List includes places of outstanding heritage value to the nation, and the Commonwealth Heritage List includes heritage places owned or controlled by the Commonwealth.

2I Australian Heritage Commission and Helen Armstrong, "Migrant Heritage Places in Australia: A Handbook for Group Coordinators," I995; Australian Heritage Commission and Helen Armstrong, Protecting Local Heritage Places: A Guide for Communities, I998. The more comprehensive kit was deposited at the National Library of Australia in 2000.

22 Notwithstanding European migration since 1788. In Australian heritage registers, this appears as "early settler" or European "pioneer" history, rather than part of a longer immigration past or a history of indigenous dispossession that is ongoing.

23 Australian Heritage Database, "Bonegilla Migrant Camp - Block 19, 76 Bonegilla Rd, Bonegilla, VIC, Australia," Department of the Environment, Australian Government, 20r4; Snowy 
surrounding such monuments celebrating Australia's migration history falsely represent the nation's historic and ongoing mistreatment of migrants, as well as migrant agency within these restrictive situations. State-sanctioned migrant heritage sites, like the Snowy and Bonegilla Migrant Reception Centre, offer a version of migration history that stresses progress, national efficiency, modernization, development, and harmonious transition-silencing structural inequality and difference, material hardship, migrant resistance and protest, racial tensions, economic and social segregation, and marginalization. ${ }^{24}$ They are reworked, not as markers of an assimilationist past in which people's movements and employment were controlled and limited, but as integral to the making of modern state multiculturalism.

\section{Theorizing Multiculturalism: Critical Heritage Studies}

As indicated, state multiculturalism in Australia has posed limits on the types of histories elevated into the realm of heritage. But community-initiated monuments contain kernels of resistance and details about the past that challenge the limits of present multicultural and heritage-backed discourses associated with official migration history. This is notwithstanding the obvious power structures contained in the monuments' broader symbolic power, and their success in gaining state and federal funding, in the case of Gippsland. Accordingly, this example of migration heritage will be situated within its respective social, cultural and political contexts-with an eye to local variants, and the on-the-ground personalities and decisions that shaped its material reality.

My analysis draws on critical heritage studies scholars, especially Cristóbal Gnecco on heritage in "multicultural times," Laurajane Smith on authorized heritage discourses, and Jo Littler and Roshi Naidoo on the intersections between representations of cultural diversity, inequality, and power. ${ }^{25}$ More than a decade ago, Naidoo and Littler called for scholars to interrogate how cultural diversity and social exclusion (those well-circulated buzzwords) are acted out in modern heritage culture: in whose interest is cultural diversity promoted or rejected, and to shore up which networks or nodal points of power? ${ }^{26}$

In his discussion of heritage, Gnecco frames multicultural heritage as a commodity and a device that is technical and regulated by state and multilateral agencies; this multiculturalism masks the lived inequalities of populations in favor of

Mountain Scheme, Australian Government, Department of the Environment and Energy http:// www.environment.gov.au/heritage/places/national/snowy-mountains-scheme.

24 Paul Ashton, “'The Birthplace of Australian Multiculturalism?' Retrospective Commemoration, Participatory Memorialisation and Official Heritage," International Journal of Heritage Studies I5, no. 5 (September 2009): 38I-98

25 Cristóbal Gnecco, "Heritage in Multicultural Times," in The Palgrave Handbook of Contemporary Heritage Research (London: Palgrave Macmillan, 2015) 266-67; Laurajane Smith, Uses of Heritage (London: Routledge, 2007); Jo Littler and Roshi Naidoo, "White Past, Multicultural Present: Heritage and National Stories," in Cultural Heritage: Critical Concepts in Media and Cultural Studies, Volume 11, ed. Laurajane Smith (Oxon: Routledge), IoI-I3.

26 Littler and Naidoo, "White Past, Multicultural Present," I05. 
a "phantasmatic diversity." He refers to the limits of recognition for minority groups and to constraints on their ability to command space in public forums and change prevailing power structures-which also recalls Tariq Modood's reading of multiculturalism's shortcomings. ${ }^{27}$ Although I adopt specific examples of heritage in an Australian multicultural context that engages with a nationally bound migration history, Gnecco's consideration of broader institutional uses of multiculturalism is worth considering when critiquing how Gippsland's grassroots committee engages with, and implicitly challenges, state multiculturalism:

the multicultural conviviality of cultural diversity has not meant recognizing the worth of the different but merely its existence, which has thus been organized and, to a large extent, isolated... Real and lived inequalities have been masked by a phantasmatic diversity. The result is perversely violent: unbearable inequalities appear as desirable diversities. ${ }^{28}$

Introducing Gippsland Immigration Park: Regional Contexts

The Gippsland Immigration Park (GIP) is situated in Morwell, a small postindustrial town in the southeast of the State of Victoria. Morwell, like its closest neighbor Moe, is an economically depressed town grappling with how best to preserve or move on from its coal mining past and the environmentally and socially disruptive remnants of that industry. The main towns in the region of the Latrobe ValleyMorwell, Moe, and Traralgon-were once key contributors to Victoria's mining boom, providing the state with up to 80 percent of its power. With the exception of Traralgon, these towns are now experiencing economic hardship, low youth employment, and a declining population after privatization from the i99os. Morwell power station and briquette factory was closed in 20I4, and Hazelwood followed in 2017 .

The park was launched in 2007. I have classified it as a community-initiated monument because the conception, construction, and continual maintenance of the park is overseen by a committee of local residents who hold no formal affiliation with state or local governments or heritage bodies. The director of the GIP Committee, local resident Don Di Fabrizio, was behind the initial push for a park. All members of the committee are volunteers and have a connection to local Italian community groups. They were originally members of the larger Italian Australian Coordinating Committee for Gippsland.

In forming the idea to build some sort of monument or park to migration, the group made the decision that the park should speak to "all migrants in the region," including pre-WWII arrivals, indeed including all but Indigenous peoples. The GIP Committee has subsequently received almost a million dollars in local, state, and 20I3).

27 Tariq Modood, Multiculturalism: A Civic Idea, $2^{\text {nd }}$ Edition (Cambridge: Polity Press, 2007, 28 Gnecco, "Heritage in Multicultural Times," 266-67. 
national funding to erect and maintain the park. In the design of the park itself and the memory-work surrounding the park, they offer one version of a community narrative that focuses on the intersections between migration and labor, and it is not a consensus one. Their version of migration to (and out of) the region is not always in line with national and politically endorsed collective memories of progress and postwar industrialization.

Due to the long-term impacts of coal mining, the region of the Latrobe Valley has never been a picturesque tourist destination. The park was unlikely to become a site of tourism. Its aims are commemorative and community minded. It is used by local groups and associations for various events throughout the year, including the Gippsland Multicultural Festival which features heavily the voices of newer migrant community groups to the region, such as Filipino and Indian groups. ${ }^{29}$

Achieving Recognition: Gippsland as Multicultural Heritage and Grant Applications

By the GIP Committee's own admission, the park seeks to "celebrate" and "honor" migrant arrivals and their "contributions," both cultural and economic. At face value, the park seems to offer a "harmony in diversity" narrative of multiculturalism that supports positivist readings of Australian migration history.

The GIP Committee gained funding from the Public Records Office of Victoria's Local History Grants, the Department for Victorian Communities, the Multicultural Community Infrastructure Fund administered by the Office of Multicultural Affairs and Citizenship and the Victorian Multicultural Commission, and the Latrobe Valley Community Facility Fund. Since 2005, they have been successful in almost every grant application they submitted. However, as one GIP Committee member noted, they were not always successful in gaining grants specifically offered for "heritage" projects. Although the GIP Committee viewed the park as pertaining directly to their and the local region's "heritage," funding bodies instead defined this term according to extant physical "fabric." But as Helen Armstrong identified in the late I99os, much of the physical fabric (the tangible heritage) pertaining to postwar migration-the immigrant clubs and associations, Department of Immigration reception centers or "camps" near rural towns, inconspicuous places of worship, inner-city markets and early migrant neighborhoodshas been demolished in the redevelopment of cities since the I970s. ${ }^{30}$ The creation of new fabric, the building or refashioning of commemorative spaces like Gippsland Immigration Park, becomes especially important in this context. As one GIP Committee member identified, however, heritage funding was not always able to recognize this:

29 Gippsland Ethnic Communities Council website, http://www.gippslandethniccommunities council.websyte.com.au/site.cfm?/gippslandethniccommunitiescouncil/2/.

30 Helen Armstrong, "Migrant Heritage Places in Australia," Historic Environment 13, no. 2 (I997): I2-23. 
At that time, they [heritage grant bodies] were funding more things to do with heritage buildings and restoration. Out of all of this, after that, there's been a movement to multiculturalism and through the multicultural department, we have got funding since then, on different projects, little ones. The enhancements to the area, this part of it here, is migration, multiculturalism, right here. Anything we did to improve that fitted in with their criteria. ${ }^{31}$

The GIP Committee identified a "movement to multiculturalism" in the industry at a state level and was subsequently able to amass small grants pertaining to this multiculturalism in order to construct parts of the park. It was in 2oIr that Heritage Victoria (supported by the Heritage Council of Victoria) completed a pilot project titled "Victoria's Post I940s Migration Heritage."32 Much like the AHC "Migrant Heritage in Australia Kit" that came before it, the project identified a lack of migrant heritage places and collections in national and elite institutions and registers. State bodies were receptive, therefore, to supporting community projects that adhered to celebratory versions of multiculturalism, even if Heritage Victoria failed to follow up this pilot project with further funding and ongoing consultations with community groups.

Institutional definitions of "multiculturalism" certainly shaped the tone and language adopted in various grant applications by the GIP Committee: they stressed the role of migrants in making "a significant and enduring contribution to the development of Gippsland," leaving the nature of this "contribution" vague, but privileging a concept of Australian history as one of progress. ${ }^{33}$ In my discussions with the GIP Committee, they indicated that they were motivated by a vaguely celebratory multicultural rhetoric endorsed by the state, one of "unity in diversity." However, they also approached this rhetoric with a strong sense of what was excluded: the messy, the human, the nonlinear, and the unsettled nature of migration in and out of the region.

\section{The Wall of Recognition-Linear Pasts and Migrant Mobility}

The wall, featuring the names of migrants, is a familiar feature of migration's public history in Australia. In institutional settings it appears as an all-inclusive gesture to the importance of migration to nation-building: since 1999, the Maritime Museum of Australia has maintained a "Welcome Wall,"34 the Immigration Museum in

3I Serge Auciello, interview with the author, February 7, 2018, Morwell, Victoria.

32 Accessible at https://www.heritage.vic.gov.au/research-and-publications/thematic-andtypological-studies/victorias-post-I940s-migration-heritage-study.

33 Gippsland Immigration Park committee's Application Form: Victorian Community Support Grants, 2006.

34 There are currently 29,949 names on the Welcome Wall. It is undergoing an upgrade so it can accommodate more names. The Maritime Museum also has an online welcome wall, with written stories uploaded by members of the public. See https://www.sea.museum/discover/welcome-wall. The Tribute Garden in Melbourne has been full since the Museum opened in the late rg9os, but they 


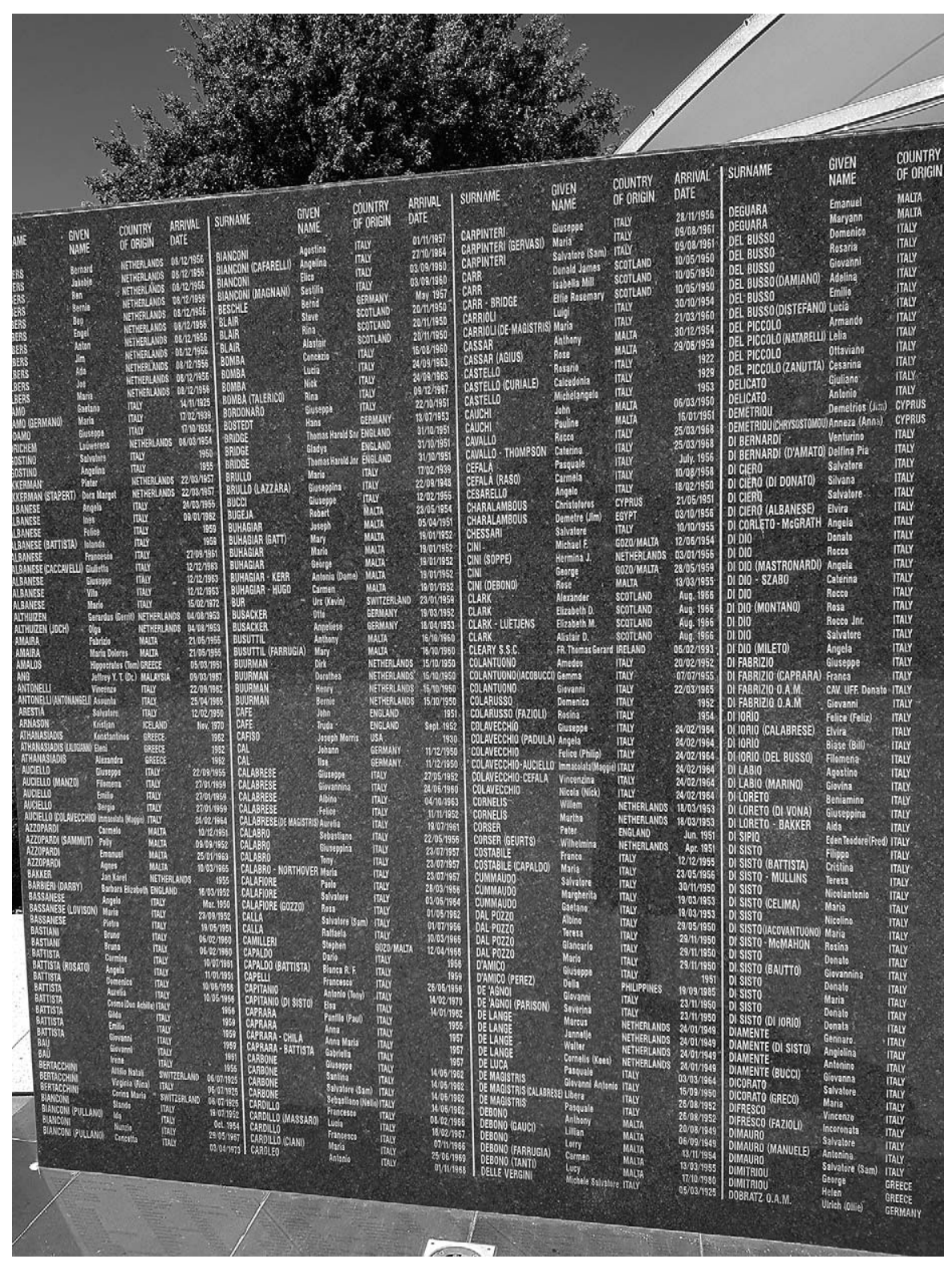

A segment of Gippsland Immigration Park's Wall of Recognition, in Morwell, Victoria, Australia. (Photo taken by the author)

Melbourne has a "tribute garden" that lists the names of immigrants, and Bonegilla Heritage Park has a small but growing wall of names. ${ }^{35}$

accept online stories via their "Share a Story" database. See https://museumsvictoria.com.au/ immigrationmuseum/whats-on/discovery-centre/.

35 For more on Australia's migrant walls, see Eureka Henrich, "Paying Tribute: Migrant Memorial Walls and the 'Nation of Immigrants," in The Culture of Migration: Politics, Aesthetics and Histories, ed. S. Pultz Moslund, A. Ring Peterson, and M. Schramm (London: I. B. Tauris, 2015), 327-46. 
The names that appear on the wall are arranged according to the year in which they were listed-each March or April, the GIP Committee hosts an unveiling ceremony for the addition of new names. Notably, not all names are "immigrants" per se. Some are migrants who have moved back and forth, and many no longer live in the Gippsland region, or even in Australia. The GIP Committee was clear that these names needed to be included, for this experience reflected the reality of twentieth century mobility, especially for those displaced by temporary conflict, or undertaking work contracts, and not necessarily seeking permanent settlement, although the latter dominates celebratory depictions of the postwar immigration scheme. The thing that binds these names together is their presence (but not settlement) as migrants in the region-most of whom sought work, often temporary, in the local power stations. Each year, the unveiling ceremonies attract people from across the country, and sometimes overseas. Even as the park participates in a specifically regional celebration of migrant contributions, it is unavoidably part of a national and transnational network of memory. The Wall of Recognition, therefore, seeks recognition for this oft-recognized aspect of the migration narrative.

\section{Migrant Labor and Industrial Development: Don Di Fabrizio, the Director}

The statue at the center of the park also speaks to migrant mobility-but in reference to a specific historic context, which relates to the director of the GIP Committee, Don Di Fabrizio, a postwar migrant from the Abruzzo region of Italy. The bronze, realist statue rests at the center of the park, hedged by the Walls of Recognition. It is of a young man, clutching a bag and shielding his eyes from the sun with his passport. His garb is I950s vintage. His expression is unreadable, neither pleased nor upset. He represents those able-bodied young, single men targeted by the Department of Immigration in the postwar era. His stance also comments on their precarious situation: the GIP Committee explained that it is intentionally unclear if he is coming or going. When historicized, the statue has something very specific to say about the situation facing single migrant men in this era: the uncertainty of their journey within Australia, and the isolation of their experiences in rural areas in the full swing of industrialization.

Don migrated in 1954 as a single young adult under assisted passage-half his passage was covered by the Australian government in exchange for two years of government-directed labor, and the other half was covered by a loan from the Italian Institute of Credit for Italian Labor Abroad (ICLE). His brother had already migrated and was working off his two-year work contract in Queensland. Despite having no experience in heavy industry, Don was placed in Geelong, near Melbourne, working for the Electric Power Transmission (EPT), where he stayed for four months. He was made to erect steel at high heights as a rigger, despite being afraid of heights. He worked from 7am to $5 \mathrm{pm}$, ate dinner at $6 \mathrm{pm}$, and then worked again from $7 \mathrm{pm}$ to Irpm-only in those four hours in the evenings were they able to unload the cut-steel that arrived by train. Don lived in a small tent for 


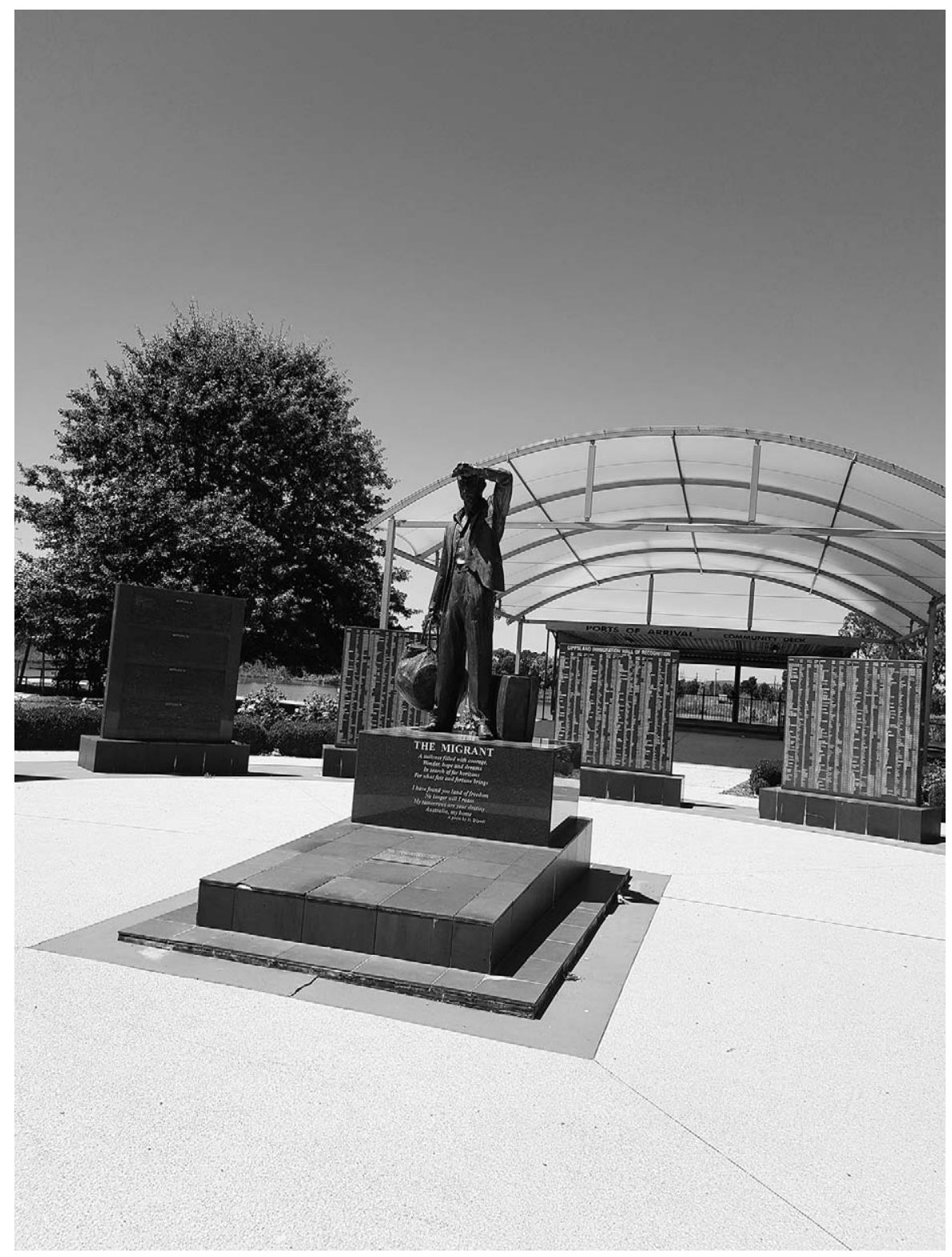

Gippsland Immigration Park showing the central statue, in Morwell, Victoria, Australia. (Photo taken by the author)

two months because the EPT worker's camp (of communal wooden barracks) was at full capacity. Despite experiencing these conditions, Don says he did not mind: his wages were good, he insists.

Don then found work in Morwell (a three-hour train ride from Geelong), undertaking steel erection for the Morwell Power Station and Briquette Factory. He eventually became qualified as a boilermaker forging rivets. Again, he lived in a tent for a few months. With a handful of other men, he constructed purpose-built 
barracks for the incoming workers, most of them assisted migrants like Don. ${ }^{36}$ Don's younger brother migrated from Italy not soon after, and all three brothers found themselves working in and around Morwell.

Although previously known for its dairy and forestry industries and the flat agricultural lands of the central Valley, the region expanded rapidly from the I920s, when power from Yallourn Power Station began to flow to Melbourne. Beginning in the I94Os, the state in the form of the State Electricity Commission of Victoria (SECV) and the Gas and Fuel Corporation invested heavily in extracting Morwell's rich coal deposits, a cheap energy source for Victoria. ${ }^{37}$ This, and a new emphasis on briquette production, saw the Latrobe Valley's brown coal industry flourish. As sociologist Jerzy Zubrzycki described in 1964, the expansion of coal and briquette factories saw the Latrobe Valley become the "industrial nerve center of Victoria." 38 The region became a focal point for new migrant arrivals: the ig6r census showed an increasing population of Dutch, Italian, German, Maltese, and Polish-origin peoples to the valley. ${ }^{39}$

Each of the brothers married, and they all lived in the same house, which they built themselves. In the I96os, they set up their own steel fabrication and erection business, based in Morwell. There was a high demand for their work from the building and construction industry in the Latrobe Valley. ${ }^{40}$ Zubrycki noted in his survey of migrant workers in the region:

there was great activity ... an air of prosperity, no doubt due to the enormous rate of recent expansion. Many of the immigrants and local Australians when interviewed spoke of it as the "boom" town, recalling the years of $1955^{-7}$ when the construction on the SEC [State Electricity Commission] undertaking was in full swing. ${ }^{41}$

Don told me that he helped build the now-infamous Hazelwood Power Station, which he was able to point to during our oral history interview; its domineering (and now redundant) façade is visible from his current home in Churchill (a township on the edge of Morwell). Hazelwood closed in March 20I7, with the Victorian Government offering up to \$266 million to help the community deal with the loss of jobs and the region's failing economy. ${ }^{42}$ But as many journalists have insisted, the region is still struggling to recover from the loss of thousands of jobs

36 Donato Di Fabrizio, cited in: Editorial Committee (Immacolata Auciello, Sergio Auciello, Donato Di Fabrizio, Graham Goulding), Stories from the Gippsland Immigration Wall of Recognition, Volume One (Gippsland Immigration Park Inc., 20I2); Donato Di Fabrizio, interview with the author, February 7, 2018, Morwell, Victoria.

37 Stephen Mark Legg, Heart of the Valley: A History of the Morwell Municipality (Melbourne: Royal Victorian Institute for the Blind, 1995), I97.

38 Jerzy Zubrzycki, Settlers of the Latrobe Valley: A Sociological Study of Immigrants in the Brown Coal Industry in Australia (Canberra: Australian National University Press, 1964).

39 Ibid., I5-6.

40 Gippsland Immigration Park Inc., Stories from the Gippsland Immigration Wall of Recognition.

4I Ibid, 20-22.

42 Rachael Brown, "Hazelwood: Victorian Government pledges \$266 million rescue fund for Latrobe Valley," ABC News, November 4, 2016. 
that occurred when the SECV was sold off by the state government in the I99os. ${ }^{43}$ Hazelwood itself was the focus of vociferous anti-coal protests throughout the 2000 , and it was often described as "Australia's dirtiest" power station. ${ }^{44}$ What to do with the remnants of the coal industry in the Latrobe Valley remains a contentious point of public debate. Don seemed unwilling to engage with these debates but is well aware of Morwell's poor economic prospects and the effects of deindustrialization. Intergenerational employment in one of the Latrobe Valley's large brown coal power stations was common; consequently, the impact on communities of privatization from the I99os and successive closures has been devastating. ${ }^{45}$ Within a couple decades of these closures, the Latrobe Valley had the highest rates of unemployment in the state.

Don and his brothers came during the postwar industrial boom. They were part of a mass immigration scheme that, at first, targeted single able-bodied young men to work in heavy industry and agriculture. The history of Italians in Australia is often told in relation to this socio-economic success and to the postwar industrial boom. ${ }^{46}$ Within the frame of celebratory state multiculturalism, there remains the risk of glossing over other structural realities of migrant settlement, the familial implications of mobility, and the long-term and ongoing issues surrounding this type of work and its remnants.

However, Don is in many ways the perfect example of the migrant success story - the one politicians love to quote and the media like to profile-a migrant entrepreneur. Below he is pictured in front of the statue, in a piece for the local Latrobe Valley Express celebrating his Latrobe City's Citizen of the Year award on Australia Day 20I6. ${ }^{47}$ But clearly his migration trajectory was not without its own difficulties and years of substandard accommodation and dangerous work. His once thriving steel business has had to downsize in recent decades, having lost its large contracts with the SECV. Other migrants of his cohort experienced further and continual mobility within Australia under the terms of their two-year work contracts with the government, a condition of their assisted passage which also mandated the separation of families according to the availability of work and accommodation. ${ }^{48}$

43 Kellie Lazzaro and staff, "Hazelwood Closure: Latrobe Valley 'Needs Jobs, Not New Pools' To Help Transition from Coal Industry," $A B C$ News, March 31, 20I7; Josh Gordon, Benjamin Preiss, Darren Gray, and Adam Morton, "Hazelwood Shutdown: \$266m Rescue Plan for the Latrobe Valley," The (Melbourne) Age, November 4, 2016.

44 Environment Victoria, "Safe Climate: Replace Hazelwood," https://environmentvictoria.org. au/campaign/replace-hazelwood/.

45 Anna Watanabe, "What Happens When a Town's Major Industry Shuts Down?" Insight SBS, February 20, 2017.

46 Franceso Ricatti's latest book adds complexity to that narrative, particularly by focussing on transcultural and transnational contexts: Francesco Ricatti, Italians in Australia: History, Memory, Identity (Cham, Switzerland, Springer, 2018).

47 Gary Stevens, "The vision to succeed," Latrobe Valley Express, January 28, 2016.

48 For more on family separation see Alexandra Dellios, "Displaced Persons, Family Separation and the Work Contract in Postwar Australia," Journal of Australian Studies 4O, no. 4 (20I6): 4I8-32. 


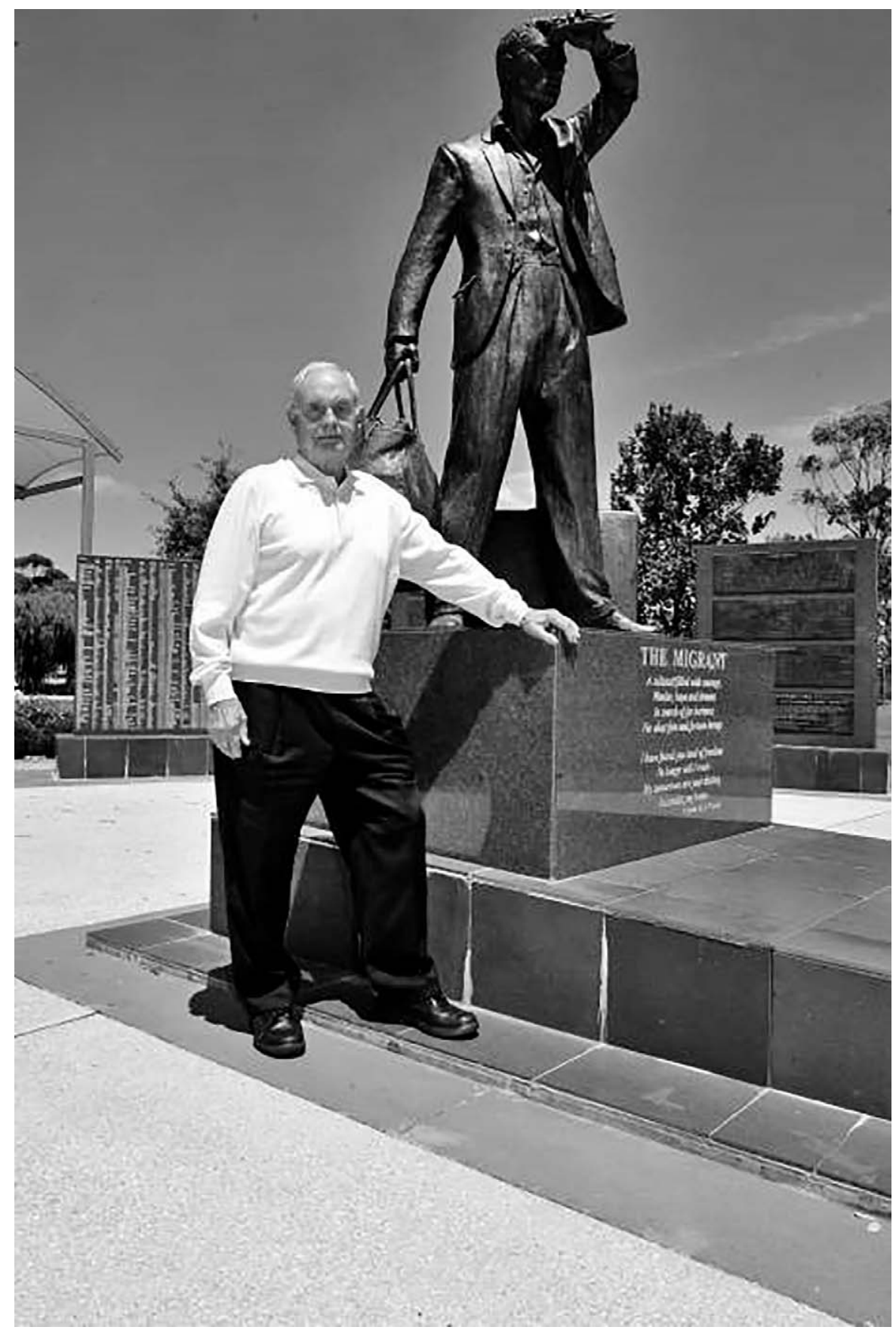

Director of the Gippsland Immigration Park Committee, Don Di Fabrizio, standing in front of the park, 20I6. (Photograph by Bryan Petts-Jones for The Latrobe Valley Express) 
In recounting this pre- and post/deindustrializing history, I am not implying that working in heavy industry was all happiness and prosperity. As historians have argued, it is hard to evoke the visceral feel of working in a coal mine. ${ }^{49}$ We are asked to think of the constant grime and soot that pervaded such industrial settlements-the cantankerous noise and the smell of noxious effluent. The local press complained about air pollution, although the smell that many out-of-towners noted probably came from the Australian Paper Manufacturers Ltd's pulp and paper mill in nearby Maryvale, built in the late 1930 Os. $^{50}$ Decades later, in the I980s, research revealed that the coal dust was not nearly as damaging to public health as the asbestos used in power plants as fireproof insulation. In the I970s and earlier, local groups bemoaned the creation of an industrial wasteland-“as gloomy as West Germany's Ruhr Valley"and the loss of a rural identity. ${ }^{51}$ These aspects of industry are harder to represent in a monument or statue. Also, while the region was relatively unscathed by global oil crises in the I970s, the period was still one of heightened industrial action on the part of several unions. ${ }^{52}$ Hard-earned fights over workers' rights and migrant rights to citizenship and union representation occurred in tandem with rising concerns over the environmental impact of the coal industry and toxic industrial waste in the Valley. ${ }^{53}$ Many of the names that appear on the Wall of Recognition are of those who campaigned for migrant and workers' rights throughout the I96os and I97os.

To summarize, from the I940s the communities within the Latrobe Valley grappled with rapid industrialization, and the environmental and social impacts of that transformation, alongside receiving and integrating a large and diverse influx of new migrant arrivals. Although full-employment and job security for multiple generations employed by the SECV was a feature of these decades, so too was industrial dispute, substandard accommodation, and a governmental inability to deal with public health issues linked to the coal industry. ${ }^{54}$ These less savory aspects of the recent past are difficult to capture in a statue of a lone male migrant; arguably a larger, more multi-vocal and multi-platform initiative would be needed to tackle this contested historical terrain.

49 And many industrial heritage sites fail to do so. See critique by Stefan Berger and Paul Pickering, "Regions of Heavy Industry and Their Heritage," in Industrial Heritage and Regional Identities, ed. Christian Wicke, Stefan Berger, and Jana Golombek (London: Routledge, 20I8), 2I4-I5.

50 "It's a Death-Trap, says Morwell," The Argus (Melbourne, Victoria), July 6, I955; "M.P. Protests Over Gas Plant 'Nuisance from Dust, Smoke and Grit," Record (Emerald Hill, Victoria), November I2, I949; See also Legg, Heart of the Valley, I97-20I.

5I Fuel for Unrest: People, Power And Planning In The Latrobe Valley (Melbourne: Brown Coal Study Group, Published by the Conservation Council of Victoria, I98I). Ironically, the Ruhr is now held up as a shining example of the "successful mastering of de-industrialisation ... arguably also the precondition for the valorisation of industrial heritage in the region." Berger and Pickering, "Regions of Heavy Industry and Their Heritage," 2I7.

52 The Gippsland Institute of Advanced Education to the Town and Country Planning Board, State Electricity Commission of Victoria, Country Roads Board, Central Gippsland Social Survey: A Socio-Economic Study of the Latrobe Valley: A Report (Melbourne: C. H. Rixon, govt. printer), I975.

53 Legg, Heart of the Valley, 298.

54 Ibid., 280-99. 


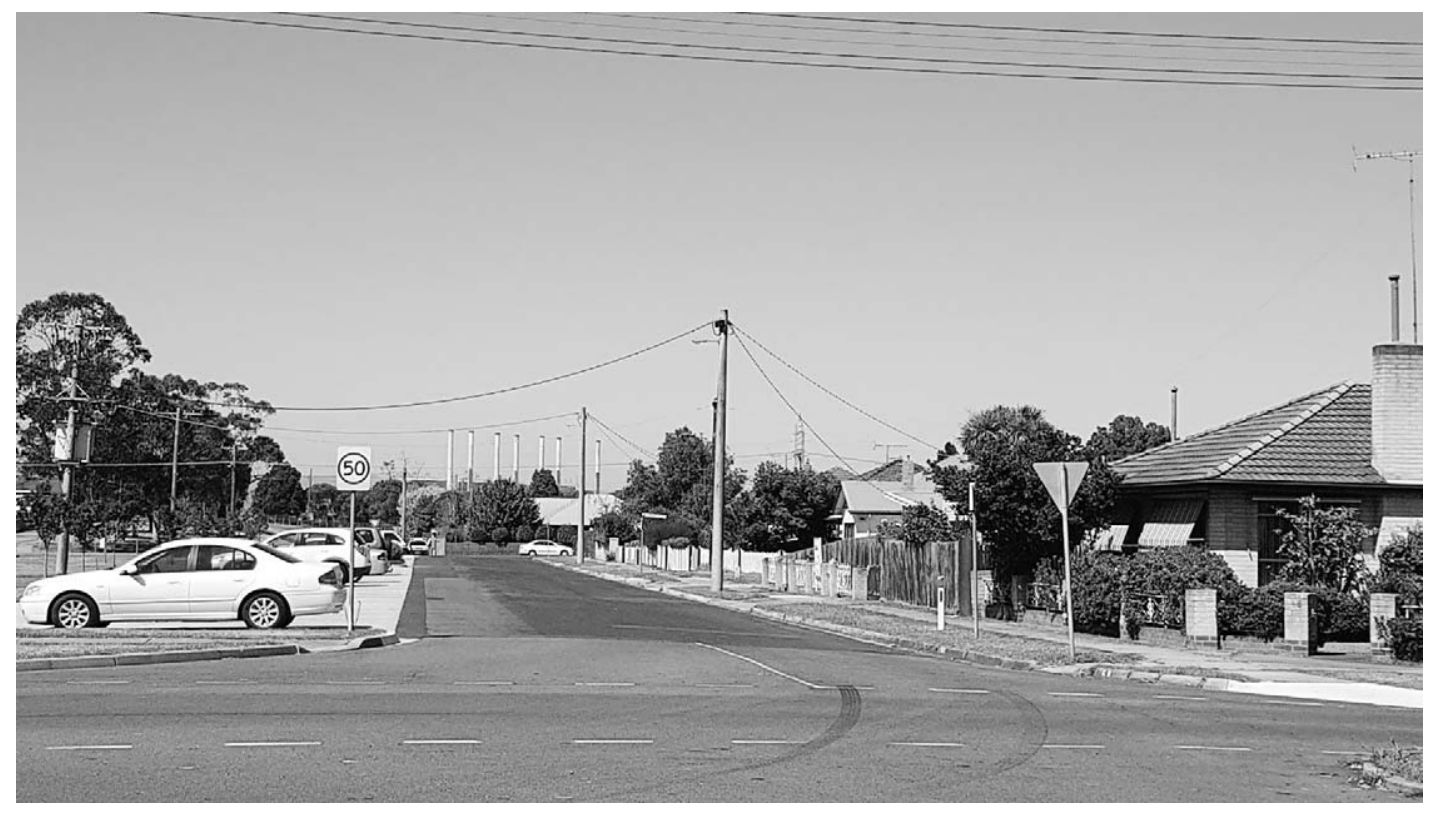

View of Morwell Power Station from Morwell Library, March 20I9. (Photo taken by the author)

To return to Don: like many Italian men, he and his brothers had little knowledge of the specific conditions of their work in Australia before agreeing to assisted passage and signing their two-year work contracts. Like the Eastern European refugees before them, they were bound by a labor contract that ensured their loneliness and isolation in rural areas, at the same time as it provided stable employment (except during periods of economic downturn). ${ }^{55}$ Historian Karen Agutter describes the work contract as creating an "endless parade of people being shifted from place to place" throughout the 1950 and well into the 1960s. ${ }^{56}$ Her description of postwar settlement under the contract system as a "continuum of mobility" is important to bear in mind when reading the statue. It must also be said that while many single Italian men did not intend to stay in Australia, the stakes of their emigration journey were still high: they had dependents back home, for whom their wages would provide, and their loan from the ICLE had to be paid off. Many did return to Italy in the 1960s-when the rates of emigration out of Australia exceeded immigration, especially among Italian and Dutch origin cohorts. ${ }^{57}$ This is an oft-recognized fact in the wider history of Australia's mass immigration scheme.

55 Zora Simic, "Bachelors of Misery and Proxy Brides: Marriage, Migration and Assimilation, 1947-1973," History Australia II, no. I (2014): I49-74.

56 Karen Agutter, "Displaced Persons and the 'Continuum of Mobility' in the South Australian Hostel System," in On the Wing: Mobility Before and After Emigration to Australia, Visible Immigrants Vol 7, ed. Margrette Kleinig and Eric Richards (Melbourne: Anchor Books: 2013), 136-52.

57 Stephen Castles, "Italians in Australia: The Impact of a Recent Migration on the Culture and Society of a Postcolonial Nation," Center for Migration Studies special issue, II, no. 3 (1994): 346. 
The statue, then, is reflective of Don's experience, and also challenges some long-standing popular tropes about postwar migrant success as linear settlement and token or vague cultural contributions. I referred earlier to Don's visual reference point of Hazelwood, which he helped build. He has also written about migrants "building the region," by which he means literally, materially. ${ }^{58}$ Accordingly, the physicality of the male migrant statue at Gippsland Immigration Park is important-the stance of the man, his able-bodiedness. Although Don described himself as slight and malnourished when he arrived in Australia in 1954, he describes his co-workers in opposite terms. During our conversations, Don also referred frequently to the structures he has built-his first home in Morwell, Hazelwood station, and the migrant barracks. ${ }^{59}$ These structures aren't officially recognized as "heritage-worthy," but they feature prominently in the memories of many migrant families who spent time in migrant accommodation and worked in heavy industry. Most important here, however, is the labor that built these memory places: the migrant labor represented in the statue. Rather than struggle to gain heritage recognition for existing structures in Morwell, the GIP Committee built (out of nothing) a heritage place that recognized a migrant past that intersects with the region's industrial heritage.

This representation is, however, limited to a particular experience-male and able-bodied. The statue holds its own ability to silence and sideline alterative histories, of women and people of color in multicultural Australia. The limits of the monument's symbolic rhetoric reflect current power structures evident within the GIP Committee and within some Ethnic Communities Councils and ethnically aligned community groups Australia-wide-many of which are still led by the first and second generation of postwar migrant men from continental Europe. The park therefore re-centers able-bodied men as the image of postwar migration, even as it works to destabilize the presumption of migrant progress, linear settlement, and belonging.

Nonetheless, when read as a monument to mobility and immobility in postwar Australia, the statue participates in a destabilizing discourse of alternative histories-destabilizing the stability of celebratory heritage in a multicultural context. Accordingly, the monument ought not be read as masking power relations through the offer of "a phantasmatic diversity," as Gnecco argues. ${ }^{60}$ The plaques and Wall of Recognition that fringe the statue work to question some aspects of multicultural discourse: difference is here historicized, and visually depicted alongside representations of state-backed industry and its dependence on migrant labor.

The park cannot but negotiate complex and conflicting local and national histories, given the historic intersections between migrant labor, heavy industry, and the state's policing of expressions of cultural diversity. In this way, the GIP

58 Cav. Uff. Don Di Fabrizio O.A.M forward in Stories from the Gippsland Immigration Wall of Recognition.

59 Donato Di Fabrizio interview with the author, February 16, 2019, Morwell, Victoria.

60 Gnecco, "Heritage in Multicultural Times," 269. 
Committee, the park, and the memory platforms it offers challenge the favored mode of discussing migration as a linear progression towards settlement, integration, and belonging.

\section{The Plaques-Labor Pasts and Industrial Heritage}

The bronze plaques on two of the seven walls that fringe the statue depict statebacked industry and migrant labor. They offer a number of tropes common to public histories of Australian immigration: mass migration is implicated in the nation building process and the postwar industrial boom. One plaque labelled "major projects" contains images of all the coal mines and briquette factories in the region-including Morwell power and briquette factory, Hazelwood power station, and Yallourn power station. As indicated, some of the physical remains of this industry still dominate the Morwell skyline. The images at the park are concerned not only with an industrial past, but also a working-class past; they are centered on working migrant peoples undertaking physical labor in heavy industry. This working class past tends to stress the physicality of work, and avoids directly addressing racialized difference. ${ }^{61}$ I do not read these plaques as "fetishized sites of the state," a monument to the state-backed coal industry and/or State Electricity Commission of Victoria-the theme "working life," for example, warrants a whole wall, and major projects, only a plaque. ${ }^{62}$

Industrials pasts and working life have been marginal to Morwell's heritage agenda. Historical societies and council-backed "heritage walks" of the town completely exclude this aspect of the town's history, focusing instead on earlier farming traditions and early European civic buildings. ${ }^{63}$ Historian Erik Eklund recently argued, agreeing with earlier statements by public historians like Peter Spearritt, that industrial heritage has been marginal to Australia's heritage landscape. ${ }^{64} \mathrm{He}$ refers to "Australia's premier colonial industrial site" in Newcastle, the Coal River Heritage Precinct, which has been unsuccessful in its four separate community attempts to be listed on the National Heritage List, as evidence of the marginal status of industrial heritage in Australia. ${ }^{65}$ There are parallels to be drawn between the Latrobe Valley and Newcastle in the Hunter Region-both (in)famous for their

6I For more on working class heritage, see: Laurajane Smith, Paul A. Shackel, and Gary Campbell, eds., Heritage, Labour, and the Working Classes (London: Routledge, 20II).

62 Michael Rothberg, Multidirectional Memory: Remembering the Holocaust in the Age of Decolonization (Palo Alto: Stanford University Press, 2009), 20.

63 Stephen Hellings, Heritage Fact File: A Brief Look at Some Dates Names and Events (Morwell: Morwell Historical Society, 20oI); Stephen Hellings, Footsteps Through Time: A Heritage Walk Depicting The Morwell Of Yester-Year (Morwell: Morwell Historical Society, 20or); Stephen Hellings, Morwell: Memories and Milestones (Morwell: Morwell Historical Society, 1999); Debbie Edwards, Morwell, a historical walk (Victoria: D. Edwards, 1993).

64 Erik Eklund, “There Needs to Be Something There for People to Remember': Industrial Heritage in Newcastle and the Hunter Valley, Australia," in Industrial Heritage and Regional Identities, ed. Christian Wicke, Stefan Berger, and Jana Golombek (London: Routledge, 2018), I68-89.

65 Ibid., I8I. 


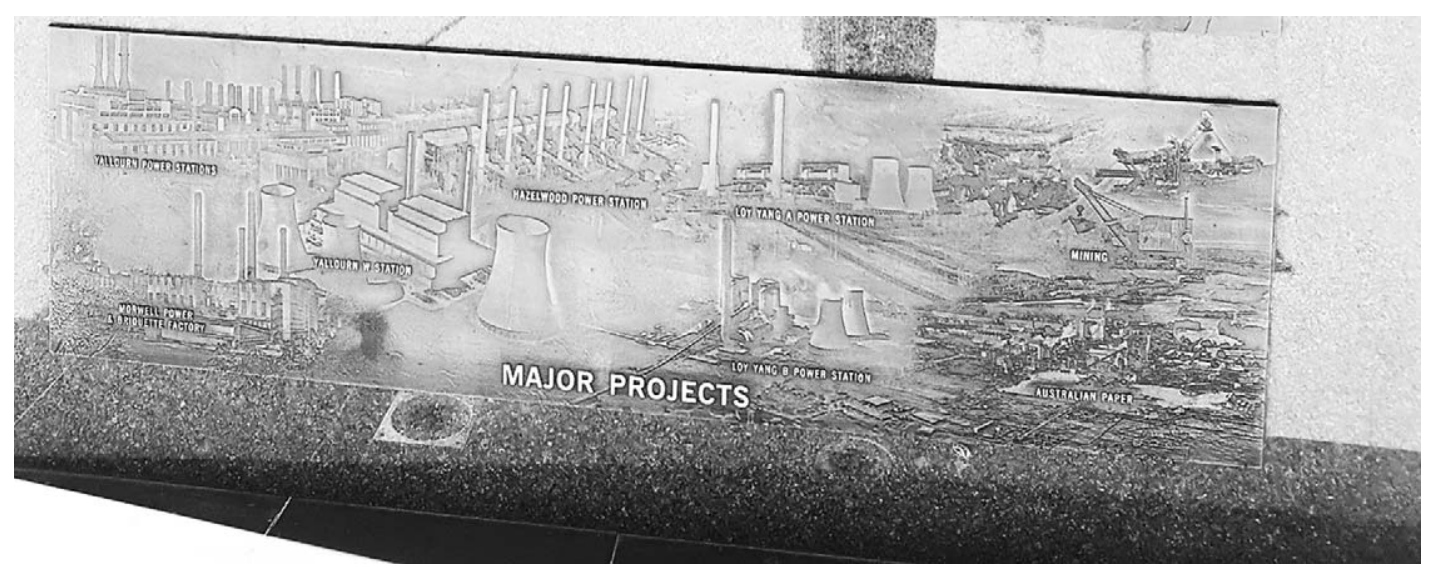

One plaque on one wall of the Gippsland Immigration Park, in in Morwell, Victoria, Australia. (Photo taken by the author)

coal, and limited in their depictions of regional identity as male, blue-collar and Anglo-Australian. The recognition of industrial heritage encountered some failures in Newcastle, despite the strength of community groups like the Newcastle Industrial Heritage Association and the re-emergence of the steel industry. The Latrobe Valley and the wider Gippsland region also share the same historical tensions as the Hunter Valley-with some heritage proponents preferring to privilege an earlier farming tradition.

In this context, the Gippsland Immigration Park created an entire wall dedicated to "working life," depicting earlier work in the timber industry, in coal mines, in construction, and in small business. The images are mainly of working men. Another wall depicts educational and artistic "achievements," and another "settling in," evidenced through the establishment of sporting and cultural clubs. Instead of reading this as a multicultural symbolic realm in which "diversity" is depoliticized, as per Gnecco's framework, I want to suggest that these plaques and the park as a whole offer layered and potentially contentious histories of labor and industry.

That is, this sometimes celebratory and nostalgic depiction of power stations (as well as the difficulties of working life) in the Latrobe Valley also draws attention to the deleterious effects of privatization on the region. This concern is especially pertinent given the makeup of the GIP Committee and the local and multigenerational migrant audience they wished to address. Each GIP Committee member had family migration stories that were intimately tied to the fortunes of the local power stations and other large public works that employed hundreds of thousands of postwar migrants under often arduous working conditions in the I95os and I96os as outlined above. In some ways, the monument could be read as a mode through which elements of the migrant community (including Don's and subsequent generations) mediated and made sense of these drastic economic changes to their region. I read the park, in one sense, as a monument to failed industry and migrant uncertainty. Most importantly, the park sidelines token expression of 


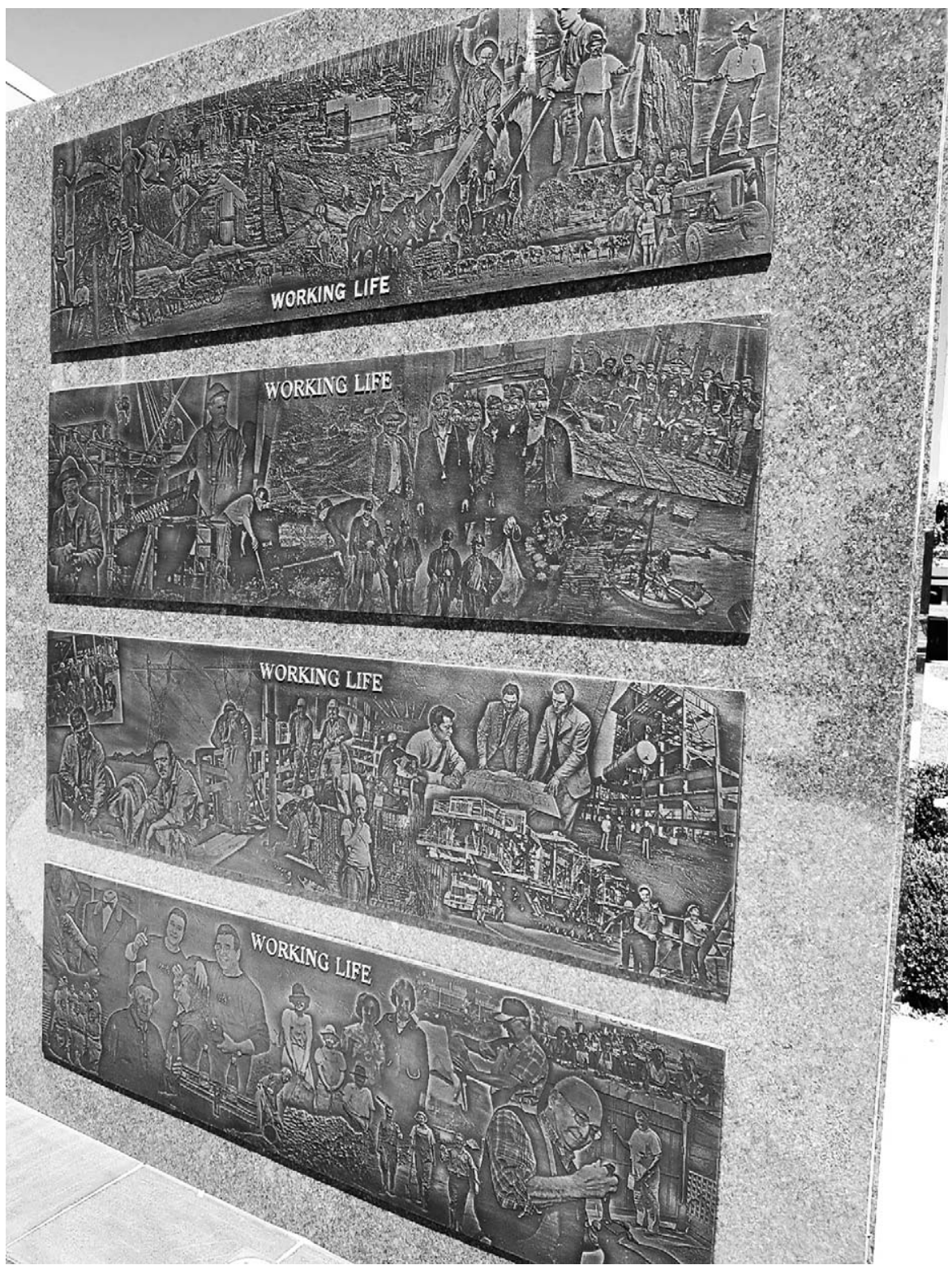

One wall of the Gippsland Immigration Park, in in Morwell, Victoria, Australia. (Photo taken by the author)

"ethnic contributions" (food and folklore) in favor of depicting material conditions and structural integration into the region.

What to Do with Industrial Heritage in the Latrobe Valley?

Working class and industrial heritage is a growing field of study in the critical heritage studies literature. Here, I want to stress its obvious intersections with 
migrant heritage-an intersection that is less explored in the literature. Cheryl Wragg, a resident in the town of Moe, has been a lone advocate for the industrial heritage of the Latrobe Valley. Her father, George Wragg, was an English migrant who arrived in the valley in 1956 to take up work as a SECV shop steward. He also worked to reform the Central Gippsland Trades and Labor Council and participated in the SECV strike in $1977 .{ }^{66}$ Her familial past, therefore, is intimately connected to the industrial heritage of the region, like that of members of the GIP Committee. When the Victorian Heritage Council, in February 2018, decided to include the Morwell Power Station and briquette factory on the Victorian Heritage Register, Wragg called it "the first step in creating an industrial heritage site of national and international significance," and holds hope for it triggering a "whole new large industrial tourism industry activity in our region." Her position does not reflect all community views: even a cursory glance at newspaper commentary on the matter, or a search of Facebook groups on the region's history, reveal heated debate over the fate of the physical remains of industry. Historian Erik Eklund, in response to the listing, also noted the strong community sentiment that it was the "wrong choice for the site," citing high unemployment and an aging population as reasons why the region may not be ready for the commodification or "touristification" of the coal industry-in addition to the not-so-fond memories of industry I outlined above. The recently released documentary "Our Power: The Latrobe Valley, Hazelwood, and Our Energy Future" directly addressed these memories, focusing on "the effects of the privatization in the I990s, which severely demoralized the community's pride in electricity production." ${ }^{\prime 67}$

Even if we are to frame this heritage as labor heritage, rather than industrial heritage-that is, from the perspective of working people represented in the Gippsland Immigration Park-there remains the issue of bitter memories. I mentioned above the migrant groups who experienced unfair working conditions, poor housing, and limits to their economic advancement, as well as those families now dealing with youth unemployment, after generations of work in the coal industry. How does the valley reconcile those experiences with the need to foster community memory? Far from being the only answer to a lack of physical conservation of former power stations, the park is simply one attempt to deal with this past and safeguard this industrial and migrant heritage.

The Centre for Gippsland Studies (CGS), based at Federation University, which has a campus in Morwell, aims to provide a forum for the exchange of ideas between community and academic researchers, including a space to discuss what happens to the remnants of industry. They advocate for the protection and conservation of industrial heritage and bemoan the "violent process" of large-scale demolition, and its psychological and social impacts. In one online

66 George Wragg, Fourpence to Join (Queensland: Left Press, 20r6).

67 Cited in Peter Yacono, "Our Power: The Latrobe Valley, Hazelwood, And Our Energy Future," Green Agenda, February 26, 2019. 
exercise, in which the CGS compared images of the landscape with and without industrial remains, they invited the public "to view these images and prepare for a post-industrial landscape without any major tangible heritage." The comments were heated and sometimes adversarial. Here is a small sample from four commentators:

"Get rid of the bloody eyesores! For years those stinking chimneys were the view out my front window. I don't care how they come down but the idea that they should stay is an utter joke!"

"You can't be serious... it's one thing to save a beautiful mansion or an historic cottage ... but a concrete behemoth eyesore?!?!

"I agree with her Ioo\%, rip em down!"

"Can't wait to see all that ugly stuff gone so we have a better view of the beautiful valley that surrounds us." 68

I am not implying that these are consensus community views-but, combined with other public commentary, they do indicate that the issue of industrial heritage is far from resolved in the Latrobe Valley. Local communities have also voiced concern over the environmental impacts of industry, especially since 2014 when a massive coal mine fire at Hazelwood's disused open-cut mine covered Morwell in toxic smoke and ash. It blazed for over a month. ${ }^{69}$

Celebrating industrial heritage is therefore wrought with many complex emotions, not all of them celebratory. There may be scope for adaptive reuse that somehow speaks to the industrial past (or rather the labor heritage, the working class lives) implicated in the fortunes of these former power stations, but it would fail if it does not also address the structural inequalities and family lives that the Gippsland Immigration Park attempts to depict. In this case, the Latrobe Valley is not unique among regions formerly dominated by heavy industry. ${ }^{70}$ The aim of the GSC speaks to this concern: working-class communities faced with deindustrialization also face the destruction of sites for collective memory. On the flip side, the desire to revitalize regional economies through the heritagization or touristification of industrial structures might not fulfil all community needs-as Eklund argues above. Certainly, the Gippsland Immigration Park does not fulfil all of these needs, as it ignores environmental legacies, and does not afford as much agency to women and non-European migrants in building the region.

However, through its focus on working conditions, continued mobility, and the working-class individuals and families behind the physical remains of industry, the

68 Centre for Gippsland Studies, Facebook Group comments, July 25-September 16, 2019.

69 See in particular, Jillian Blackman et al., "Hazelwood Health Study Adult Survey, Volume 2: The Relationship between Hazelwood Mine Fire Smoke Exposure and Health Outcomes," November 22, 2018.

70 Wicke, Berger, and Golombek, Industrial Heritage and Regional Identities. 
park enables other memory work, aiding conversations about postwar inequalities and government stipulations that could contain the spatial mobility and settlement experiences of migrant others. These migrants are defined by more than just their ethnic contributions to a white managerial multicultural nation-state. I'm not suggesting that what's left here is only a representation of the migrant as economic agent. Rather, they are mobile members of families who were constrained by material conditions in a sometimes-paternalistic industrial era, and yet they also assert their need for recognition and representation-in this case, asserting their history in the region, in industry and working life, and in the cultural life of the Latrobe Valley.

\section{Conclusion}

This monument derives some of its rhetorical function from the multicultural success story. And yet, a close examination of those involved in its making, and the historical narratives they offer, hints at the monument's possibility to become a site around which histories of structural difference, inequality, and discontent may be shared. I have undertaken this analysis under the presumption that collaborative, community-initiated forms of public history have the potential to challenge and expand the boundaries of migration history and multiculturalism as it is used by official heritage in Australia. As stated, however, this memory work is not without its own silences and exclusions-there are limits to the challenge it poses to mainstream discourses around multiculturalism. I am cognizant of the GIP's silence on environmental issues and around the role of women, especially single working women, and non-European migrant groups in this industrial landscape. Other memory platforms, like the commemorative booklet Voices from the Wall, affords narrators with more diverse backgrounds the opportunity to voice alternative histories of the region, but these memory platforms are not the subject of this paper.

The Gippsland Immigration Park offers potential framings of migration history that expand and challenge the impetus of official multiculturalism to fetishize and mystify (to effectively de-historicize) difference and inequality. The GIP Committee, their grant applications to government-backed funding bodies, and the eventual park broadly appealed to a populist and positivist narrative of multicultural nationhood. But it became apparent that local and intimate or familial narratives of migration and settlement in the Latrobe Valley were also proffered-as was a focus on the material realities of migration and work.

Their funding statements adhere to narratives about national progress, but the park, its plaques, and the statue also stress economic and material conditions that structure the lived realities of diverse groups who have moved in and out of the region. Stories of economic struggle, housing difficulties, and daily working lives in the steel and coal industries, as well as continued internal mobility and family separation, are a prominent part of this community history. These stories made the park significant to implicated communities for reasons that are contrary to the 
celebratory civic pride attached to state multiculturalism, and, by extension, to official heritage.

The aim of this research is not necessarily to identify instances in which individual actors or heritage consumers challenge a positivist and sanitized version of immigration and multicultural heritage with oppositional and negative narratives (although this can be apparent), but rather to identify ways in which implicated groups (diasporic or ethnically aligned communities) use and construct historically grounded narratives of immigration (and settlement in a pre-multicultural Australia) to potentiate narrative interactions that highlight structural difference and settlement difficulties. They ultimately transgress essentialized notions of ethnicity and cultural contributions to a nationally bound conception of the mainstream. These sites are multivocal spaces, which spark disagreements over history's legacies, even as some voices are privileged above others. The meeting points, those negotiations that occur between conflicting framings of the past, are part of a process that occurs at every public history site or project.

Alexandra Dellios is a historian and lecturer in the Centre for Heritage and Museum Studies at the Australian National University. She practices oral history and is invested in collaborative community history work. 